\title{
Philosophy of a Name: Ukrainian Context
}

\section{Ad Felsefesi: Ukrayna Bağlamında}

\author{
SVITLANA KHYRIPKO (D) \\ Borys Grinchenko Kyiv University \\ GANNA IATSENKO \\ National Shipbuilding University
}

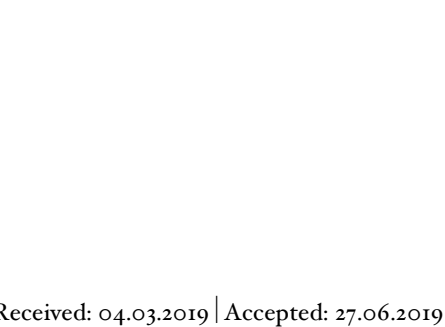

\begin{abstract}
The article is devoted to the spiritual content peculiarities issue in the process of proper nouns creation in spiritual Ukrainian culture. The true value of a name, as a philosophical, cultural, spiritual and historical phenomenon, is highlighted. The first aim of the work is to discover the specific features of names' appearance and spiritual components by structural analysis and hermeneutic methodology in cross-sections of elite-sacral, elite-secular and folk names in ancient ethnic Ukrainian tradition. The second is to analyze the valued vectors of spiritual roots in name giving culture. The third is to draw attention to the specific influence of Christianity on culture and symbolism of a name giving process. The last is to examine the current cross-section of the given problem.
\end{abstract}

Keywords: Philosophy of name, values, spirituality, anthroponomy, Ukrainians, ethnic group, ethnic culture.

(C) Khrypko, S. \& Iatsenko, G. (2019). Philosophy of a Name: Ukrainian Context. Beytulhikme An International fournal of Philosophy, 9 (2), 437-451.

\vitlana Khrypko

Borys Grinchenko Kyiv University, Faculty of History and Philosophy, Dep. of Philosophy 04212, Kyiv, Ukraine|s.khrypko@kubg.edu.ua

Svitlana Khrypko

National Shipbuilding University, IEDL, Department of Philosophy and Cultural Studies 54000, Mikolayiv, Ukraine|iats26or@gmail.com 


\section{Introduction}

A name contains some traits that are given to a person. It is a subject of proud, that can be lost, sometimes there are some arguments about its dignity, and in addition it happens to be disgraced in some cases. A name is a specific personal human title that is given to a person after a birth; it is a main attribute for a man that has often become his equivalent symbol. The name misspelling could become a reason for serious offence or motivation for a personal conflict. A name is a special word: "we consider it; we respond to it when we are applied to, therefore, a name is with us through all our life" (Savitska, \& Savitski, 20I2, p.5). A name which has embodied national tradition is precious and eternal heritage, absence of which counteracts future.

"The proper nouns contain priceless historical sources and language memos" - claims the ancient names' researcher S. Gubernachuk (Gubernachuk, 2008, p.I5I). Among functional name meanings a researcher, first of all, highlights a function of determination, individualization, socialization, a function of a personal place determination in a social structure (for instance, there were the names particularly given to lords in Kyivan Rus). Although ritual and magic name functions are crucial, especially functions of symbolic charm and protection. To continue the idea of a married couple researchers Savitsky: "Our predecessors thought that a name could determine a man's fate, moreover it was a key to a man's personality and vocation" (Savitska, \& Savitski, 20I2, p.5).

A name is a value which is with a person when he has lost absolutely all property. Nevertheless, a name can be purposely changed, when a life is started again, thus values - "are the content of a personal micro world, in the case when macro world has temporary lost its sense. A valuable thing is something that in crucial situations of existence gives personal protection, which offers a sense of personal dignity... it's an essence of a word from which a life begins when it begins from a blank sheet of paper" (Khrypko, 2009, p.II).

A name is a creation of language culture; it is a folk phenomenon, which embodies the whole historical layer with all rises and falls; it is, in some sense, a flower that could be real and simultaneously transcendental 
united with ethnical memory, culture, history, national philosophy and mentality, etc. A name phenomenon combines with a concept of cultural and historical school, and responds to a methodological formula: "le grain (grain) - la plante (plant) - le fleur (flower), consequently in any essay "a flower" corresponds to "a plant", "a plant" to "a grain" (Garasim, 2009, p.34-35).

Appealing to a famous Ukrainian folklore theorist Gerasim, we try to highlight the major accents in the given methodological formula. In other words, "a grain" in the formula is a national character, which in some measure determines pace of ethnical history - "a plant", "a plant", in its order, determines "a flower", particularly a historical event or existence on a chronological gap creates a theme or special literature plot that responds to historical time and contains its reflection (Garasim, 2009, p.34). Any Ukrainian name-surname-and father name is a text that contains the whole epoch (for instance: - Bezsmertna Katherina Bogdaniona, where Bezsmertna (immortal) - kozak surname, Katherina - ethnical context of a Christian name Katherine, Bogdaniona - pagan name Bogdan (given by God). One more example, Knish Michailo Leonidovich, where Knish - is an ancient sacral name of a ritual loaf of bread made particularly in Christmas time, which could be eaten only by members of a family (Khrypko, 20II). Michailo came from Hebrew and translated "equal to God" (Skripnik \& Dziatkivska, I996, p.79). Leonidovich came from Greek and was widely spread after Christianization. The importance of such methodological approach of studying folklore elements is in consideration of an "eternal" folklore issue, particularly the problem of interrelationships between national historical life and folklore as a metaphorical reality reflection (Garasim, 2009, p.35).

Anthroponims (Proper nouns) have been the widely used lexical phenomenon among different nations for centuries (Gerasimchuk \& Nechiporenko, 2002, p.3). As long as a name of a nation has existed this nation has been alive, while a person's name has been remembered he has been alive in human's memory. Proper nouns (anthroponims) have come to be not only the witnesses of human history (particularly history can be learnt by names), but furthermore they are landmark symbols. A name has always been equated with something or somebody, according to ancient 
beliefs: a name is an essence of a thing and a man, namely it is a defining sign of a person; in other words nothing exists until a necessity in a name arises, and vice versa, when a necessity appears to destroy something completely, erase from memory the form-spell is used, for instance: "I wish his name not to exist anymore" (Zajvoronok, 2006, p.26I). In this case we can address to modern versions of angry statements to compare: "I wish I haven't heard his name!" or "Forget his name!"etc.

A tradition to keep a name in memory even after a death of its holder connected with an ancient belief that until a name had not left a sphere of memory, a person that used to have it was still alive at least in human memory. Names acquire and embody mystical character due to old tradition, particularly to know somebody's name and say it, mean to have power under that man. This fact explains a name's role in spells and prays. Therefore, we can highlight such common phenomenon as a proper noun that is the oldest anthroponimical formation.

Among the researchers of culture and history of Ukrainian names P. Chuchka, N. Dziatkivsky, V. Gerasimchuk, S. Gubernachuk, M. Khudash, G. Lozko, A. Nechiporenko, S. Savitska, O. Savitsky and L. Skripnik should be mentioned. The enumerated researchers have represented the given issue with great devotion and consideration. Hence, their works embody "love to wisdom". Moreover, such language culture scientists as I. Farion, I. Franko, I. Suchomlin and others appeal to the problem of names-surnames dual nature. Historical and linguistic context of the old names functioning is followed in the papers of G. Bulashov, O. Buriak, Y. Gerasim, S. Khrypko, S. Nalivajko, O. Voropaj, V. Zajvoronok and in other ethno cultural studies.

The aim of the work is to highlight the specific and spiritual content of elite-sacral, elite-secular and folk names in ancient ethnic Ukrainian tradition with the structural analysis usage and hermeneutic methodology application. Moreover, the valued vectors of spiritual roots in name giving culture are to be analyzed. The last task is to examine a current crosssection of the given problem.

The semantic and sacral leadership in the process of Ukrainian names' creation goes to such called "God given names", or "God glorification names". Such names are oriented on the idea of God glorification 
according to their sounding; the idea of names' derivation from God's will is followed.

The idea of "Gods glorification" is a central one in ancient Slavic names. Slavic nation has got such name from Gods glorification, in this way such enthonim (the name of ethos, nation) is interpreted in Book of Veles. Moreover, it is a common name for all modern nations that have their roots in ancient Slavic tribes and nations. It should be noticed that there is the biggest amount of preserved names in sphere of proper names which have a root Slav- : Dobroslav, Miroslav, Slavomir, Sviatoslav, Viacheslav, Yaroslav, etc. There are names with semantic peculiarities, such as old names Slavibor (struggle glorification) and Slavoning (tenderness glorification) (Lozko, I998, p.IO7).

Additionally, the widely spread are the names which have the roots Bog- (God) or Rod- (Family): Blagorod, Bogdan (Given by God) (Skripnik \& Dziatkivska, I996, p.42), Domoroch, Radomir, Rodoslav, Zivorod, etc. Gradually, with the Christian culture spreading, these old pagan names were transformed into surnames, which was a bright feature of twobeliefs in the Ukrainian ethnic cultural tradition. The echo of old pagan God names, holidays or spirits can be heard in some modern Ukrainian surnames: Bogolub, Diduch, Knisch, Leliak, Perun, Volos, Voronko, etc. (Lozko, I998, p.6-I2).

The ancient Russian names have predominantly come to us from the sphere of classical written sources such as chronicles, documents, and ancient graffiti. Owing to the sources a logic and complete system of pagan list of proper names "sviatsi" had been built, which lexically included and depicted various functional spheres of social life: social hierarchy, the main industries and crafts, psychological peculiarities and moral values, individual traits of character and behavior, aspects of a woman's pregnancy and a child birth, appearance, and even a time of birth and birth order (Gerasimchuk \& Nechiporenko, 2002, p.8).

The secular leadership of Ukrainian names belongs to such called elite names which embodied an idea of power, dignity. Among them the priority belongs to "honorable" or "lord" names.

According to spiritual and valued features such names have compli- 
cated lexical filling and stand in one row with the bright names of Kyivan Rus, which is an evidence of word and name talents of our ancestors. These names are often comprised of two lexical roots, one of which is multi-meaning and has an ability to be composed with another roots (bor, -chval, -dar, -gost, -lub, -mil, -mir, -misl, -nig, -polk, -slav, -volod, -voi, -zar, etc.): Boguchval, Dobrolub, Dobromisl, Iziaslav, Ladimir, Ludmil, Mstibog, Pakoslav, Ratibor, Ratmir, Rogvolod, Svitozar, Volodar, Yaropolk, etc (Gerasimchuk \& Nechiporenko, 2002, p.8).

On the other hand, there are similar female names' versions derived from male examples, and have the same soundings, for instance: Boguslava, Boleslava, Ludmila, Vislava, Vseslava, etc. In addition to good soundings an honorable sense is put into in the names, where lord's responsibilities of honesty, dignity, sanctity are combined with a prophetic sense of the root "-slav" that predicts a future loud glory to a name's host.

The interesting fact is that in the chronicle "Povest vremennich lit" ("Contemporary years' narration") there are I03 names with the component -slav among 190 names presented in the literary source. As time passed, a history of names acquired modern features and even during lord's period of Kyivan Rus some names began to use in shortened form, namely from a full name only the first part was taken: Boris (from Borislav), Tvorim (from Tvorimir), Vadim (from Vadimir), etc. An aim to make name's sounding softer and put attraction, warmth, love, into it created a tendency to use some "reduced" variants with a diminutive-hypocoristic suffix. Such names were generated: Borinia (from Borislav), Lub, Luban, (from Lubomir), Putiata (from Putislav), Radko, (from Radogost), Sviatko (from Sviatoslav), Yarisch (from Yaroslav) (Lozko, I998, p.36; Gerasimchuk \& Nechiporenko, 2002, p.8-9; Savitska \& Savitski, 20I2, p.36-37).

After acquaintance with the ancient Ukrainian history of names a tendency can be highlighted which consists in traditional inclusion of well-known names with Scandinavian originals into the "lord's block" of old Russian names, namely Askold, Dir, Igor, Olga, Oleg, etc. Moreover, in accordance to the fact that they have left a deep trace in our history, some of them are widely used nowadays.

The name Bogdan deserves to pay attention to it. It is a core name of spiritual pagan period; however, it has remained its popularity in the 
era of Christian culture and even during the time of warrior atheism.

A prominent page of Ukrainian names belongs to ethnic and folk names. In Ukrainian names hierarchy they cannot be called low or less elite. However, they are unique in semantic and practical perception.

The history of common people names is also gripping and valued, as it is the history of Ukrainian nation and traditional culture development. So called "common proper nouns" carry crucial functional sense, they depict and represent traditional way of life, ancient beliefs, ethnical fantasy, historical contacts, etc. In old times a process of a name selection for a member of the family or a neighbor was submitted to a simple esthetic principle - "as it came into mind" by peasants.

The sensible sources of such "name composition" were in various unexpected spheres, namely:

- A name derived from a craft: Kozemiaka (Tanner);

- A name derived from the use of social position features: Diak (Clerk), Igumen (Hegumen), Posol (Ambassador), Selianin (Peasant), Vladika (Lord);

- A name derived from national background or ethnical features: Cheremis, Mordvin, Tatarin (Tatar);

- A name derived from stress necessity and stressing some traits of appearance or character: Chornogolov (with dark hair), Guba (has distinct lips), Loban (has a distinct forehead), Rozumnik (a bright boy), Schulga (a leftbanded man), Riabiy (with red hair), Tugodum (is not bright in thinking), Ugrim $(\operatorname{moody})$;

- A name derived from different names of animals, birds, fishes, insects, etc.: Baran (ram), Gornostay (weasel), Gusak (goose), forsch (roughy), Kit (whale), Lin (tench), Mucha (fly), Okun (bass), Solovey (nightingale), Soroka (magpie), Zuk (bug), Som (catfish), Sterliag (sturgeon), Sudak (pike), Vovk (wolf), Zaets (hair).

- The names derived from animal names were accepted for granted and later even the whole families took the names as Levitchi (derived from lion), Vedmeditchi (derived from bear), Volkovitchi (derived from wolf), etc., and in further the names were transformed into surnames.

- A name derived from a plant name: Goroch (pea), Kapusta (cabbage), Zito (wheat), etc. A famous folk Ukrainian song which has such lyrics: 
"Garbuz (Mr. Pumpkin) is walking through a vegetable garden and asking where is his family" can be assumed to be a real illustration of a particular family with such family name.

- A name can be derived from a birth place in a family, namely, Pervuscha or Pervak (the first), Vtoruscha (the second), Tretiak (the third) etc. till to the tenth child. Such rule is especially typical for large families.

- A name can be given due to a year's season in accordance with a religious or traditional calendar: Miasoid (feast), Miasopust (fasting), Moroz (frost), Podosen (autumn), Politko (summer), Zima (winter). The names (Miasoid and Miasopust) have a common name of memorial weeks.

- A name derived from some character features of a child. The names illustrate a character of a newborn from the first days of life, when a baby gives some troubles for all family especially during night hours: Bezson (sleepless nights), Budylo (to wake up), Buyan, Reva (cry), Gam (ruckus), Schumilo (to make noise), etc.

- A name derived due to the prophetic word spell belief. A name's choice of ancient Slavs was done according to the deep belief that a name would influence on the whole person's life, namely, it could fill it with bright and valued actions or ruin everything up to the end, might be a reason of total misfortune, and even might lead to death of its holder. Owing to this reason only "trusted persons" had an access to a name's choice among them were parents, trusted relatives, witch-doctors, women-birth attendances who in most cases had great respect from local community. Protected power of name charms in our ancestors' beliefs was associated with the common notions of life, health, power, nature. The realization of such associations was embodied in the following names: Byk (bull), Dub (oak), Silan or Silobor (powered man), Zalizo (iron), etc.

- A name came from a parents' wish to ensure a good, prospective child's fate without poverty and misfortunes in financial sphere. The realization of such wish can be met in some funny names: Borsch (traditional soup with beat) and Kapustiak (traditional soup with cabbage), Kascha and Kulisch (porridge), Salo (fat), etc.

- A name created according to "another side" glance of the prophetic word spell belief. It was meant that some parents were terribly afraid of bad spiritual influence on a child and gave him "a bad name" (a name with 
negative features) purposely. It was a kind of spell, a charm from a bad eye. Such tendency had created a row of strange, unfriendly names: Bida (calamity), Bolvan (stupid man), Bovvan (a kind of pagan god), Klia (spell), Nechai or Nezdan (unexpected), Nekras (ugly man), Nelub (unloved), Nenasch (stranger), Nevdacha (misfortune), Rozgildiaj (chimney sweep), etc. The social component could be suggested in the given names. For a number of reasons a next child in a poor, deprived family could be unwanted (as a child ought to be fed and required appropriate life conditions) and parents' desperation could reach high levels. Therefore, such tendency was reflected in a name creation process and presented in a child's name. The special attention should be paid to a mentioned name Bolvan. The offensive features of a name which could be noticed from a first glance, it gained during early Christian times of Kyivan Rus. However, at the ancient pagan times when the name was created, it had "divine" origins and meant "light" as bovvanits were the sources of light. The functions of charm (all spells neutralization) had a lot of other names their source was in a belief that there were natural powers which could dispel all the magic. The powers are mentioned in the following names: Muchomor (fly agaric), Osa (wasp), Perets (paper), Poloz (corn snake), Pugach (somebody you can scare), Tsybulia (onion), Vuz (snake), etc.

- A name created according to a level of parents' love and expectation. Such children were lucky as they obtained tender, good sounding names that became a real beautification of folk name collection: Bogdan (given by God), Bogolip (made by God), Dobrynia (kind), Dobrilo (good-hearted), Druzina (social), Gost (guest), Lubim (beloved), Malinka (tender), Milan (cute), Miluta (sweet), Zdan (expected); the female names - Dana (given by God), Krasunia (pretty), Lada (attractive), Lelia (nice), Liolia (was born in a shirt lucky), Lubascha (beloved), Lubomila (beloved), Milonoga (sweet), Miluscha (cute). The parents' expectations to see a child lucky, attractive, brilliant, wit, rich were the background of the "wished" names, among them: Chemnii (well behaved), Chvalim (honored), Lagoda (female) or Ladim (male) (attractive), Poticha (consolation), Tichii (quite). The parents who adored their children gave them "the luckiest" names derived from the words God and Angel: Angelina, Anzela, Anzelika, Bozena - the female variants were presented. The parents' love embodied in such names was to protect 
children, supplied them with good fate and brought lucky in the future for them.

Furthermore, some mentioned names have resembled nicknames: Kisil, Kislitsa, Ktsiokvas, Zirnos. A popularity of a nickname influenced on a name, so a person could be known exceptionally by it. Nicknames were a base of Ukrainian surnames creation. In this case we could appeal to Gogol's literary heritage who worked rigorously with Ukrainian anthroponims and a complex of bright surnames in his works was composed by the ancient real Ukrainian surnames-nicknames: Bulba (derived from potato), Chaliava (derived from an opportunity obtaining something for free without any work for it), Dovgouch (derived from long ears), Motuzocbka (derived from a rope), Remin (derived from a belt), Sverbiguz (derived from scratch), etc. (Gerasimchuk \& Nechiporenko, 2002, p.I2).

We have considered almost all context and the reasons of naming in the above-mentioned list. Having examined the whole catalogue of names which were given by our ancestors and having conceived a valued context of each name we could make a conclusion that the vast majority of names had been left in a history or had lost their valued potential. The so called "lords' names" (male and female) have been popular up to date, nevertheless so called "folk names" have come into surnames' sphere under the better circumstances.

The epoch of creativity, rich fantasy and names' choice independence in Kyivan Rus had gradually come to end as Christian culture arrived. Christianity is not only a monotheistic religion or unique integral worldview ideology; moreover it is a way of life, moral regulation, and eventually, traditions and ceremonies, one of which is baptism. In personal light of Christian culture the ceremony of baptism obtained the main role of naming. To baptize, to name, to accept into Christian community became synonyms. "A process of a name obtaining" was an ancient tradition connected with a name selection process for a newborn. A doula went to a regional priest with presents among which was a loaf of bread as a compulsory element; her aim was to "obtain a name". Traditionally, a name was given in honor of a saint, according to a day of an infant birth (Zajvoronok, 2006).

Despite all the efforts a church could not destroy or erase from hu- 
mans' memory the traditional folk ceremonies and names connected with them. The period of double names had lasted for a long time and got a name of "anthroponimic scissors". Naming had two stages: firstly a child got a primary name in a family according to the ancient traditions, and then he obtained a secondary Christian name at a baptism ceremony due to the church book "sviatsi" or church calendar. As a result, having had two names a newborn was in protection of two sources: pagan and Christian. It could be suggested that the situation suited both sides. According to historical sources our lords "neophytes" had two names: Volodimir Monomach, Yaroslav Mudryi, and a lot of persons with the names of Igor, Vsevolod, etc. All of them were known in history by their secular names, despite they had already have church ones. A long unnoticed tough struggle between the ancient pagan and church anthroponimic traditions had lasted for centuries. Such opposition created curiosities: a newborn baby got one Christian name, but he also received another Christian name in that case according to the church calendar at a ceremony of baptism. There was one more gripping fact about the usage of "pagan" names, namely, they were found in church chronicles of Kyivo-Pecherskaya Lavra and belonged to XVI-XVII centuries, among them: Kischka (cat), Kisil (fruit jelly), Mizinets (pinkie,) Soroka (magpie), Straschilo (ugly man), Zaba (frog) (Gerasimchuk \& Nechiporenko, 2002, p.I4).

Almost all ancient pagan names were erased from nation's memory in the middle of XVII century when a church had a broad campaign to forget secular names. As a result in XVIII-XIX centuries Old Russian names were excluded from usage and had been completely forgotten. The Saint Sinod (Church Consultative Body) (in Russia in the period after Peter the Great) carefully controlled the process of all newborn naming from all social layers, they ought to get particularly church names belonged to the Orthodox Church. However, the social inequality could be followed. Common people obtained names precisely according to church books ("sviatsi"); moreover, in most cases a name's sounding left to be better. On the other hand, some concessions were made to noble men: the names were taken also from sviatsi, but were rare with good sounding. They gave names: Konstantin, Oleksandra, Oleksandr, Olga, Sergei, in comparison common men were: Chveska, Chivriam, Dokia, Fedor, Galka, Gor- 
pina, Ivan, Melanka, Panka, Priska (Paraska), etc. Sometimes common people got such names which could not even be spelled. The process of Christian names spreading was completed before XIX century. A person with Old Russian name could be rarely met. Nevertheless, not all Orthodox Church names remained their original sounding, some of them were transformed, distorted, remodeled with letters losses at the beginning or end of a word. As a result folk names were created on the base of church ones: Avraam became Abram, Avksentiy - Oksen, Ekaterina - Katerina, Elizaveta - Lizaveta Ioasaph - Foseph, Iakim - Yakim, Ignatiy - Gnat, Facob Yakov, Kiprian - Kuprian, Vasiliy - Vasil. Avakum (the God's bugs) became Abakum, Agafon - Gapon, Agafangel - Fanko, Arsen - Senko, Atanas - Panas (Gerasimchuk \& Nechiporenko, 2002, p.15; Skripnik \& Dziatkivska, I996, p.35-42).

Some female names were "lucky", namely, Vera (faith), Nadezda (hope), Lubov (love). They were simply translated from Greek original (Pistis, Elpis, Agape) into native language without any transformation, therefore became widely loved at once. People had always been creative to everything that was imposed and suited it to language capacities and traditions.

After Ukraine has gained independence a process of Old Russian names revival has started. The following names have reappeared: Askold, Bronislav, Lada, Lelia, Miroslav, Ratibor, Rurik, Ruslan, Sviatoslav, Tamila, Vladislav, Vsevolod, Yaroslav, Zoriana. The most popular are "historical names" - Igor and Roksolana.

Despite the fact of foreign names usage in modern Ukraine the majority of them have gained national traits. Ivan, Katerina, Kiril, Maksim, Maria, Mykola, Taras, Vasil - and many other names from "sviatsi" are accepted as Ukrainian ones. Many female foreign names have obtained special national sounding and traits: Christina, Darina, Oksana, Orina, Roksolana, Solomia, Tatiana, Uliana, Yarina, etc. Diminutive-hypocoristic name forms can be assumed to be ethnic national creation: Andriyko, Bogdas, Borisko, Dmitrik, Ivasik, Lubania, Michas, Petrik, Pilinko, Slavko, Tischko, Vasilko, etc. Some of these forms have become extremely popular among artists, writers, actors, directors, namely: Les, Lesia, Oles, Olesia (derived from Oleksandr and Oleksandra).

In spite of "magic" context popularity in name roots, it is obvious 
that not all men with the name Slava are glorious, and not all women with the name Svitlana carry light, not all men named Vladimir are lords of the world, and not all men named Yaroslav are full of energy, etc.

To conclude we can assume that any name is only a form which ought to be fulfilled by a spiritual sense of its holder. To choose a kind of spiritual content is a personal life choice.

A name is a crucial word for each person. The meaning of a word and intonation with which it is voiced could become a reason for happiness or sadness, eager response or unwillingness to hear or see a person who is calling by name.

The modern Ukrainian tradition of name giving is a bright collection of various traditions. Everyone could gain a name which was an elite and sacral in ancient times (Lada, Lelia, Rada, Mokosha) (Khrypko, 2012; Khrypko, 20I6), everyone could have a surname that embodied ancient sacral sense (Perun, Vischun, Veles, Stribog, Dobromir, Vseslav, Bogumir, etc.), everyone could obtain elite and secular names which after the Christianization of Ukraine was exclusively given to the lords (male names: Konstantin, Oleksandr, Vladimir, etc.; female names: Anna, Katerina, etc.). Moreover, folk names have become surnames: Kozemiaka (a person who deals with leather), Schulga (left-handed man), Kulish (porridge), Vdovchuk (a widower), Nenchin and Materinchin (someone who belongs to a mother) (Khrypko, 2012).

Our names are simultaneously private and public embodiments of our "self". It is cultural, spiritual and symbolic treasure that contains our vocation, experience, power, wisdoms and generation memory.

\section{References}

Boriak, O. (2006). Ukraine: the Ethnocultural Mosaic. Kyiv: Lubid.

Bulashov, G. (1992). Ukrainians in their Legends and Religious Beliefs: Ukrainian Cosmogonicals Folk Beliefs. Kyiv: Dovira.

Voropaj, O. (1993). The Traditions of our Nation: Ethnographical Description. Kyiv: Oberig.

Garasim, Y. (2009). The Description of Ukrainian Folklore History. Kyiv: Knowledge.

Gerasimchuk, V. \& Nechiporenko, A. (2002). Anthroponims: History and Modern 
Times. Kamianetz-Podolski: Knowledge.

Gubernachuk, S. (2008). The Treasure of Tripolska Era in Ukrainian Geographical Names and Proper Nouns. Kyiv: The Fourth Tide.

Zajvoronok, V. (2006). The Signs of Ukrainian Ethnoculture. Kyiv: Dovira.

Zajvoronok, V. (2007). Ukrainian Ethno Linguistics. Kyiv: Dovira.

Lozko, G. (1995). Ukrainian Folklore. Kyiv: Zodiak-EKO.

Lozko, G. (1998). Names: Slavic, Historical and Mythological Names. Kyiv: Svarog.

Lozko, G. (2006). Awaken Eneja: European Ethnoreligious Renaissance. Kharkiv: Div.

Lozko, G. (20II). Native Names. Slavic Names' Collection. Ternopol: Mandrivets.

Nalivajko, S. (2007). Ethnical History of Ancient Ukraine. Kyiv: Eschan-Zillia.

Savitska, S. \& Savitski, O. (2012). The Names Collection: Slavic Names. Ternopol: Mandrivets.

Skripnik, L. \& Dziatkivska, N. (1996). The Proper Names. Kyiv: Scientific Thought.

Suchomlin, I. (1970). Ukrainian Surnames as Proper Names. Speech and Onomastics of Naddniprianschina, $\mathrm{I2}, 30-58$.

Franko, I. (1982). The Reasons of Ukrainian Onomastics. 36 vols. Kyiv: Scientific Thought.

Khrypko, S. (2014). Spiritual Focuses of a Name Giving Culture: Names' Ethno Genesis and Ancient Ukrainian Names Collection. Scientific fournal of $\mathrm{Na}$ tional Pedagogical University Named after M.P. Dragomanov, 32, IO-I8.

Khrypko, S. (2012). A Widow's Figure in Ukrainian and Biblical Tradition. Scientific Journal of National Pedagogical University Named after M.P. Dragomanov, 28, 7-25.

Khrypko, S. (20I2). Venuses of Tripoli and Ukrainian Madonnas - A Prayer to Heaven Earthly Embodied. Scientific Fournal of National Pedagogical University Named after M.P. Dragomanov, 27, 16-23.

Khrypko, S. (2009). Education Phenomenon Discourse of Axiology and Cultural Studies: Valued, Mental, National and Scientific Components. Kyiv: National Pedagogical University Named after M.P. Dragomanov Press.

Khrypko, S. (2016). The Spiritual Heritage of Ukrainian Ethnic Culture: Beliefs, Mythological Images, Demonology. Scientific fournal of National Pedagogical University Named after M.P. Dragomanov, 36, 27-36.

Khrypko, S. (20II). Ethnical and Mental Dualism in Spiritual and Religious Dis- 
plays of Ukrainian Sacral Tradition. Cultural Studies, 4, I89-I97.

Khrypko, S. (20II). The Sacral Feature of Bread as Spiritual Mystery of Ukrainian Christmas Eve Tradition. Scientific Fournal of National Pedagogical University Named after M.P. Dragomanov, 26, 13-24.

Khrypko, S. (2003). Spiritual and Religious Features of Ukrainian Mentality. Kyiv: National Pedagogical University Named after M.P. Dragomanov Press.

Khudash, M. (1977). From the History of Ukrainian Anthroponomics. Kyiv: Scientific Thought.

Chuchka, P. (20II). The Slavic Proper Nouns: Historical and Etymological Dictionary. Uzgorod: Lira.

Öz: Makale, manevi Ukrayna kültüründe uygun isimler olușturma sürecinde manevi içerik özellikleri konusuna ayrılmıștır. Bir ismin felsefi, kültürel, manevi ve tarihi bir olgu olarak gerçek değeri vurgulanır. Çalıșmanın ilk amacı, eski etnik Ukrayna geleneğindeki seçkin-sakral, seçkin-laik ve halk isimlerinin enine kesitlerinde yapısal analiz ve yorum metodolojisi ile isimlerin görünüm ve ruhsal bileșenlerinin spesifik özelliklerini keșfetmektir. İkincisi, isim veren kültürdeki manevi köklerin değerli vektörlerini analiz etmektir. Üçüncüsü, Hristiyanlı̆̆ın kültür ve isim verme sürecinin sembolizmine özgü etkisine dikkat çekmektir. Sonuncusu ise, verilen sorunun mevcut kesitini incelemektir.

Anahtar Kelimeler: Ad felsefesi, değerler, maneviyat, antroponomi, Uktaynalılar, entik grup, etnik kültür. 


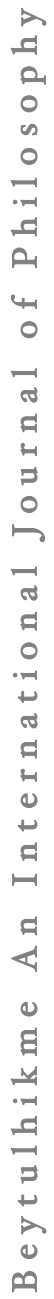

